\title{
Teaching Reform of Foreign Exchange Business in Higher Vocational Colleges-- Based on Students' Interest and Ability
}

\author{
Rong Li \\ Zhejiang Business College 310053, Hangzhou, China.
}

Keywords: foreign exchange business, classroom teaching reform, students' interest.

\begin{abstract}
. the curriculum is a breadth of foreign exchange business, have very strong course, comprehensive, practical and time course of these characteristics, the decision to the traditional teaching mode is difficult to achieve the desired effect, must reform the classroom teaching mode. The introduction of the "weekly financial hot spot review" combines case teaching, inquiry learning and multimedia teaching methods to stimulate students' interest in learning and to have a good teaching effect.
\end{abstract}

\section{Introduction}

The development requirement of education in higher vocational colleges is based on curriculum reform. It is necessary to reform the traditional classroom teaching mode and innovate the teaching mode which is suitable for education. Only by doing "teaching, doing middle school" can we achieve results. The teaching reform of education in higher vocational colleges should establish the cultivation mode with the ability as the center and establish the "heavy ability and heavy quality"; The concept of educating people with heavy knowledge is more important. In teaching, we not only focus on strengthening students' ability, but also pay attention to students' quality. Not only to impart knowledge, but also to impart skills. Combine the knowledge point with the ability point, strengthen the student basic operation skill, the specialized technical application ability and the comprehensive practice ability cultivation.

The degree of deepening economic and financial globalization and integration, especially after the party 18 large, China's financial industry opening to the outside world, the internationalisation of the renminbi becomes urgent and inevitable, society needs a lot of knowledge of international finance theory, and people familiar with the international financial practice. The foreign exchange business is under the condition of open economy analysis and research of international currency flow and motion law, international finance business, international monetary and financial relations and the realization of the internal and external equilibrium problems of course, is a wide range, strong comprehensive, practical and time course. The course covers the issue of RMB exchange rate, foreign exchange speculation and preservation and balance of payments, which are closely related to China's current economic situation and international economic situation. [1]

\section{Characteristics and Teaching Status of Foreign Exchange Business.}

The course of foreign exchange business is an elective course of Zhejiang business vocational college. This course is based on the training program of professional talents of the college, which aims to cultivate high-skilled professionals with foreign exchange trading operation and analytical and practical ability to adapt to employment. Follow in the process of curriculum construction "to adapt to market demand, strengthen their professional skills, highlight vocational ability" principle, with the core of project team members of the investment and financial management teaching and research section, to carry out the teaching material write, laboratory construction, course construction, etc, to the course construction to conform to the requirements of the construction of demonstration, conform to the goal of talent cultivation of high quality courses. 
Why is the foreign exchange business always associated with "difficulty" in the eyes of students? From the two aspects of teachers and students to think deeply about the reasons, can help us better improve the foreign exchange business classroom teaching effect to provide reference.

(1) The characteristics of foreign exchange business courses.

First of all, the content of the course of the foreign exchange business as the economic and financial globalization is becoming more and more widely, from basic theory to practical application, to the study of relevant financial policy, at the same time the course itself has a lot of obscure jargon, theory of knowledge, involving the covering range.

Second, the foreign exchange business of the teaching goal by student of international payment, foreign exchange markets, foreign exchange rates and international financial market, capital flows, monetary system, financial risk management, and other basic concepts, theories, principles, control measures and time lag effect of train students to understand and grasp correctly grasp the domestic and international major international financial problems between the observation and analysis, and through certain training in practice so that the students learn to integrated application of what they have learned to solve practical problems, but also the quality education for the students social science. Therefore, the course of foreign exchange business is both theoretical and practical.

Finally, the international financial market rapidly changing makes the exchange rate system, financial markets and regulation and international economic policies such as financial theory in order to adapt to international economic development trend, needs to constantly adjust to realize mutual coordination, therefore, the time course and has a strong "foreign exchange business".

(2) Main problems in the classroom teaching of foreign exchange business.

Training students' practical ability and innovative spirit is the core content of education teaching in vocational colleges. At present, many students in finance majors in schools lack the understanding of the operation of enterprises, and they are generally not adapted to the situation at the beginning of the society.

Teachers are the organizers of teaching activities, so teachers' ideas and teaching methods have great influence on students' learning. In the process of multimedia teaching, students pay more attention to note-taking rather than the understanding of basic principles and analysis of cases. Written on diligence, thinking on the lazy, although classroom order is good, but the content of the students because of can't understand what they have learned, the more the lack of independent ability to analyze the related problems of foreign exchange business.

The practice of teaching of the course of the foreign exchange business has become more and more deeply felt, currently adopted by the single lectures and assignments, exams the teaching method of combining the passive learning of students, make between theory and practice, influence the update of the teaching content and teaching effect. To solve this problem, need to choose from the curriculum knowledge system of foreign exchange business must have a knowledge of the junction point, let the students into the role, change passive learning into active learning, fully tap the students' learning potential, promote the improvement of teaching effects and students' comprehensive quality.

\section{The Course Teaching Reform Direction and Implementation Plan of Foreign Exchange Business.}

1. construction objectives of the course. The foreign exchange business course planning focus on training students' foreign exchange actual operation ability, and therefore in the arrangement of teaching content should be strengthened in the combination of theory with practice, the basic concept, principle, on the basis of the fundamental analysis of the key learning foreign exchange and trade skills. In understanding the management of the relevant national laws and regulations, on the basis of understanding of our country at present the main way of foreign exchange transactions and products, so that the students in the future to be able to quickly adapt to the needs of the market for talent, improve students' employment ability.

Of the curriculum, the foreign exchange business to adapt to the requirement of higher vocational education, to cultivate students' practical operating ability as the main target, and construction to meet 
the need of teaching, simulation of simulated trading of foreign exchange of laboratory, reform the traditional teaching mode, construction dominated by training courses. Courses in order to realize the knowledge network, expand the route of transmission of knowledge and mode of transmission, make the teaching means more diverse and novel, maximum limit to attract students, increase students' interest in this course.

The teaching reform of foreign exchange business should make students understand the function of foreign exchange business as a safe haven and investment in the course of teaching. Therefore, how to stimulate students' curiosity in teaching process is the direction of reform. To this end, we should pay attention to the following problems during the reform process.

2.Course reform direction. First of all, should pay attention to the teaching content and the teaching method is interesting. Teachers should understand students' existing knowledge and information reserves, find points of interest to students, and relate them to foreign exchange knowledge, so that students are familiar with it. In teaching method, we should make full use of multimedia and network to improve the interest and vividness of the course. Time is money and information is fleeting. The daily trading volume of foreign exchange market is huge, and some news factors and significant time will directly affect the trend of foreign exchange market. Introducing "financial hotspot in a week", the exploratory simulation teaching, case teaching and the organic combination of multimedia teaching means, mobilize students' learning interest, strive to play a good teaching effect.

Second, should pay attention to case analysis and practical link practical. Let the students "to apply" test as the learning goals, often causes the student to stay in the process of learning content to know some knowledge and memory, it can let students graduate, but for the cultivation of the students' ability is not good. In the work of teaching, the teacher to the student ability raise as the goal to design the teaching process and teaching content, focus on current event hot spot in the field of financial, help students form the habit of positive thinking, and constantly meet the reasons behind the financial events. Second, teachers should strengthen the case of foreign exchange business and the teaching design of practical operation, let students do it, and guide students to use it.

At the same time, we can organize students to combine what they have learned, discuss financial hot spots, and comment on, stimulate innovation and learn knowledge. Through continuous training, the students concerned by domestic and international economic, financial habits, master collect screening valuable news and information skills, and learn from the multiple perspectives analysis the profound reasons behind the information; On the basis of the real case of global financial crisis, guides the student to investigation and analysis of causes and effects, both enrich the teaching content, and the organic combination of a variety of teaching methods, which can effectively solve the problem of theory teaching and practice teaching. It also improves students' interest in learning and develops the ability to study and solve financial problems from economic and financial information. At the same time, constantly improve the teacher's own professional level and comprehensive ability, one step forward curriculum reform. [3]

3. To guide the course reform approach of foreign exchange business with interest-oriented teaching method.

(1) Effective and rational use of multimedia equipment for teaching. Multimedia can be words, pictures, video, shown visually rich variety of forms, such as teaching contents, enrich the teaching information, help to attract students' attention, make the classroom becomes more vivid, stimulate students interest in learning. Or through a professional web site, contact the actual questions to guide students to the latest financial information and real-time dynamic, and to expand the teaching content, through the comparison and analysis, deepen their understanding of knowledge and cognition.

(2) Use cases to carry out teaching. Case teaching is an effective means to improve the teaching effect of foreign exchange business. The actual events are more likely to arouse students' curiosity and curiosity and arouse their interest; Through the narration and analysis of the actual cases, it is helpful for students to actively recall what they have learned and try to connect with specific events to think. Finally, cultivate their ability to analyze and solve problems. 
(3)Conduct classroom discussions and innovate classroom forms. The foreign exchange business, unlike other courses, there will be a lot of problems in the current event hot spot, the practice of learning initiative to students, the "international financial hotspot in a week" collection, research and analysis process of all group practice autonomous implementation;Encourage students to actively carry out discussion and inquiry learning, and stimulate students' independent reading, independent thinking and innovative consciousness.Let the students actively participate in, play the initiative and creativity of the students, improve their knowledge structure, and develop the ability to think independently and solve problems. [4]

\section{Effect of the Reform of Foreign Exchange Business Classroom Teaching.}

"International financial hotspot in a week through class" into "international financial hotspot in a week" teaching, case teaching method, inquiry teaching, question guiding teaching method and the organic combination of modern means of multimedia. Because students participate in classroom teaching as a speaker, and the entire video, reversed transmission students to explain content do well prepared before class, stimulate students interest in learning, improve the teaching effect. Train students to search and filter information, analyze problems from different angles, solve problems and express their abilities. To cultivate and improve students' comprehensive quality, the ability to solve financial problems, and the target of team consciousness and innovative application.

The following results have been achieved since the introduction of the practice teaching reform in the "one-week international financial hot spot review".

(1) Students are very enthusiastic about classroom teaching. Due to the beginning of the course, students are introduced in detail to introduce the teaching reform idea of "one-week international financial hot spot review" and the preset incentive mechanism. Every student participates in the enthusiasm very high, all hope oneself group early turn, lest misses the expression opportunity. And in the interpretation of the continuous innovative interpretation mode, there are single interpretation, double broadcast, remote dialogue, question and answer, rotation and so on. After class, many students said that some of the courses were named after each class, and we tried to play truant, while the international finance course did not often call the roll, and we would arrive at each class.

(2) Various teaching methods are organically combined in the classroom. To speak good "international financial hotspot in a week, students from the information representation of team members to issue guidance, case evidence, to explore the root causes, scene simulation, means and forms, ins and outs of the hotspot in international financial information inquiry understand, again through the PPT, video and other modern multimedia teaching means, to all students read" international financial hotspot in a week, "to the organic combination of a variety of teaching methods in class.

(3) To improve the students' ability to express and graphic editor shear level as each class to video, and a review link, students attaches great importance to their manner, instrument, fully prepared to explain the content of the class to self digestion of materials, reasonable layout, to the related video to shear before class, group members repeatedly told by content analysis, in order to achieve the best effect, improve the ability to express and graphic editing, video shear level.

\section{Acknowledgements}

This paper is one of the research results of 2016 Teaching reform project of the Zhejiang Institute of Business Economics(SZYKTJXGGYB201606).

Li Rong (1972-), Male, from Huainan, Anhui province, Master graduate student, lecturer of Zhejiang Vocational College of Commerce; research direction: vocational education.

\section{References}

[1]. Jinwei He. Journal of Lishui University[J].2015,11:109-113. 
[2]. Penghua, Yixing Pan, Xiaojie Wan. Analysis on the reform of international finance curriculum teaching, develop goals based on students' interests and abilities. [J]. journal of heilongjiang college of education, 2011,1.

[3]. Xiaohui Long. Reform of international finance curriculum, Teaching reform based on interest-based approach. [J]. Technology outlook,2015,12.

[4]. Chunming Ye. Reform the teaching method to improve the teaching effect. [J].1999,12.

[5]. Junxiu Li. Construction and innovation of integration of engineering and engineering. [J]. Higher Professional Education,2010,4. 